Other delegates are: H. W. Beall, Ottawa, chief of the operations division of the Federal Forestry Branch; Dr. C. D. Orchard, Victoria, B.C., deputy minister of forests for the Province of British Columbia; Dr. B. M. McGugan, Ottawa, a member of the forest biology division, Science Service, Department of Agriculture; and Dr. R. W. Wellwood, Vancouver, a professor of the forestry faculty of the University of British Columbia. A delegate to the conference may be named by the British Columbia Lumber Manufacturers' Association.

The Canadian delegation will present five technical papers on the development of Canadian wallboard manufacturing, grading and utilization in Canada, Canadian forest inventories, Canadian plant protection organizations, and a special study of 70-year-old Douglas fir stand in B.C. Some members will attend a preliminary conference on forest products and take part in various pre-conference tours of Australia Aug. 12-25. The main conference will be held in various parts of Australia Aug. 26-Sept. 25 and in various parts of New Zealand Sept. 26 - Oct. 10. Some delegates will also take part in post-conference tours in New Zealand.

\title{
Entomologists To MeEt
}

The seventh annual meeting of the Entomological Society of Canada and the fifth annual meeting of the Entomological Society of Alberta will be held jointly at Lethbridge, Alta., on October 29 to 31, 1957.

\section{A. MACDONALD}

The sudden death in Ottawa on May 5, 1957, of Dr. D. A. Macdonald, former Director of the Forestry Branch, Department of Northern Affairs and National Resources, occasioned deep regret among his many friends and associates in Canada and Abroad.

Donald Angus Macdonald was born in the year 1892 and received his early education in Saint John, New Brunswick. In 1914 he graduated in Forestry from the University of New Brunswick and joined the staff of the Forestry Branch, Department of the Interior, at the Calgary District Office. During World War I, he served as a pilot in the Royal Flying Corps in France.

On returning to Canada in 1919, Dr. Macdonald rejoined the Forestry Branch and was posted to the Kamloops office in British Columbia and subsequently to the District Office in Winnipeg. In 1928 he was transferred to the Head Office of the Branch in Ottawa as Fire Protection Specialist.

Dr. Macdonald was appointed Assistant Dominion Forester in 1936, and in 1948 succeeded Mr. D. Roy Cameron as Dominion Forester. On the reorganization of the Department in 1950 , he was appointed Director of the Forestry Branch, and in the same year received the degree of Doctor of Laws from the University of New Brunswick.

During his periods of service at Kamloops and Winnipeg, Dr. Macdonald was one of the pioneers in the provision of systematic training for forest rangers. He was chiefly responsible for organizing co-operation in fire protection work between the Forestry Branch and the Royal Canadian Air Force in the Manitoba District. 
After coming to Ottawa he organized, in co-operation with the provinces, the series of standardized forest fire protection statistics which continue to the present time. He also strongly supported the fire protection research program which, among other things, developed the Wright System of Fire Danger Measurement now used by most of the forest protection organizations in Canada.

In 1939 he organized the National Forestry Program for Youth Training, which was most successful although unfortunately terminated by the war.

In 1948 he was appointed Canadian member of the Advisory Committee to the Forestry Division of the Food and Agriculture Organization of the United Nations. Dr. Macdonald represented Canadian forestry at sessions of the Conference of FAO in Washington and Rome, and attended the Third World Forestry Congress in Finland in 1949, and the Fourth Congress in India in 1954.

Dr. Macdonald was Chairman of the Forest Insect Control Board of Canada, and in 1949 was head of the Canadian delegation to the Conference on World Pulp Problems organized by FAO and held in Montreal. For many years he served as a director of the Pulp and Paper Research Institute of Canada, and as a director of the Canadian Forestry Association.

In 1952 Dr. Macdonald was Chairman of the Sixth British Commonwealth Forestry Conference, to which Canada was the host country.

Shortly before his retirement from the Federal Public Service in October 1956, Dr. Macdonald received the Annual Forest Conservation Award from the Canadian Forestry Association.

He then became a director of Hunting Technical and Exploration Services, Limited, and was actively engaged in organizing the Forestry Division of that company until shortly before his death.

Dr. Macdonald was for many years an active member of the Canadian Institute of Forestry. His interest in and support of the Ottawa Valley Section in particular will be sorely missed.

\section{A CHECK ON THE ACCURACY OF TREE HEIGHTS TAKEN FROM AERIAL PHOTOGRAPHS}

By J. R. Collins

\section{Abstract}

In the Spring of 1956 , some forty tree heights were measured by parallax bar from aerial photographs and checked against ground measurements.

The standard error of individual height estimates for all trees was \pm 6.1 feet, and for dominant trees was $上 5.1$ feet.

Estimates of maximum height for site classification can be made with excellent reliability by this method.

\section{General}

In 1955-56 an area of some 10,000 acres was cruised from aerial photographs. Photo-volume tables were set up based on detailed ground examination of five 2-acre photo plots, plus information from a standard ground cruise of an adjacent tract. The area is now being logged. A complete report and analysis of the cruise procedure will be made when figures are available for

\footnotetext{
${ }^{2} \mathrm{~T} \& \mathrm{H}$ Engineering, Vancouver, B.C.
} 